\title{
Disruption of social approach by MK-801, amphetamine, and fluoxetine in adolescent C57BL/6J mice
}

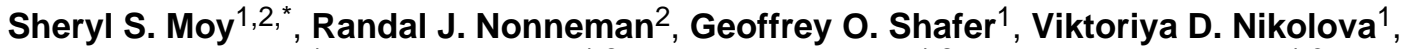 \\ Natallia V. Riddick ${ }^{1}$, Kara L. Agster ${ }^{1,2}$, Lorinda K. Baker ${ }^{1,2}$, and Darin J. Knapp ${ }^{1,3}$ \\ Randal J. Nonneman: nonneman@unc.edu; Geoffrey O. Shafer: gos@case.edu; Viktoriya D. Nikolova: \\ Viktoriya_Nikolova@med.unc.edu; Natallia V. Riddick: natallia_riddick@med.unc.edu; Kara L. Agster: \\ agster@email.unc.edu; Lorinda K. Baker: Iorinda@med.unc.edu; Darin J. Knapp: darin_knapp@med.unc.edu \\ ${ }^{1}$ Department of Psychiatry, CB\#7146, University of North Carolina School of Medicine, Chapel \\ Hill, NC 27599, USA \\ ${ }^{2}$ Carolina Institute for Developmental Disabilities, CB\#7146, University of North Carolina School \\ of Medicine, Chapel Hill, NC 27599, USA \\ ${ }^{3}$ Bowles Center for Alcohol Studies, CB\#7178, University of North Carolina School of Medicine, \\ Chapel Hill, NC 27599, USA
}

\section{Abstract}

Autism is a severe neurodevelopmental disorder, diagnosed on the basis of core behavioral symptoms. Although the mechanistic basis for the disorder is not yet known, genetic analyses have suggested a role for abnormal excitatory/inhibitory signaling systems in brain, including dysregulation of glutamatergic neurotransmission. In mice, the constitutive knockdown of NMDA receptors leads to social deficits, repetitive behavior, and self-injurious responses that reflect aspects of the autism clinical profile. However, social phenotypes differ with age: mice with reduced NMDA-receptor function exhibit hypersociability in adolescence, but markedly deficient sociability in adulthood. The present studies determined whether acute disruption of NMDA neurotransmission leads to exaggerated social approach, similar to that observed with constitutive disruption, in adolescent C57BL/6J mice. The effects of MK-801, an NMDA receptor antagonist, were compared with amphetamine, a dopamine agonist, and fluoxetine, a selective serotonin reuptake inhibitor, on performance in a three-chamber choice task. Results showed that acute treatment with MK-801 led to social approach deficits at doses without effects on entry numbers. Amphetamine also decreased social preference, but increased number of entries at every dose. Fluoxetine $(10 \mathrm{mg} / \mathrm{kg})$ had selective effects on social novelty preference. Withdrawal from a chronic ethanol regimen decreased activity, but did not attenuate sociability. Low doses of MK-801 and amphetamine were also evaluated in a marble-burying assay for repetitive behavior. MK-801, at a dose that did not disrupt sociability or alter entries, led to a profound reduction in marble-burying. Overall, these findings demonstrate that moderate alteration of NMDA, dopamine, or serotonin function can attenuate social preference in wild type mice.

() 2012 Elsevier Inc. All rights reserved.

"Corresponding author: Sheryl S. Moy, Ph.D. Carolina Institute for Developmental Disabilities, CB\#7146, University of North Carolina School of Medicine, Chapel Hill, NC 27599, USA, Phone: (919) 966-3082, Fax: (919) 966-5657, ssmoy@ med.unc.edu.

Conflict of Interest Statement

No conflicts to disclose.

Publisher's Disclaimer: This is a PDF file of an unedited manuscript that has been accepted for publication. As a service to our customers we are providing this early version of the manuscript. The manuscript will undergo copyediting, typesetting, and review of the resulting proof before it is published in its final citable form. Please note that during the production process errors may be discovered which could affect the content, and all legal disclaimers that apply to the journal pertain. 


\section{Keywords}

amphetamine; autism; ethanol withdrawal; repetitive behavior; social approach; stereotypy

\section{Introduction}

Autism spectrum disorders (ASDs) are a set of etiologically diverse neurodevelopmental syndromes characterized by three core symptoms: social interaction deficits, impaired communication, and restricted repetitive behavior. A strong heritable component for susceptibility to ASD has been supported by high concordance rates between monozygotic twins (Bailey et al. 1995, Folstein and Rosen-Sheidley 2001, Rosenberg et al. 2009). However, genetic and epidemiological studies have provided growing evidence for the importance of environmental factors in the development of the disorder (Hallmayer et al. 2011). For example, autism risk factors include maternal use of pharmaceutical agents with neurotoxic effects (Rasalam et al. 2005, Williams et al. 2001), maternal immune response to infection (Libbey et al. 2005), or exposure to environmental pollutants (Palmer et al. 2006, Shelton et al. 2012, Tian et al. 2011, Volk et al. 2011). A review by Herbert et al. (2006) identified 135 genes that have been shown to mediate responses to environmental challenge, and that are located within autism linkage regions. Overall, a complex combination of genetic predisposition and environmental contribution may underlie the broad range and differential severity of symptoms in autism.

Although the mechanistic basis for the abnormal behavioral profiles in ASD is not yet known, genetic analyses in human populations have implicated several genes important for synaptic function, including $S H A N K 3$, which encodes a member of the post-signaling complex of glutamatergic synapses, and GRIN1, which encodes the obligatory NMDAR1 subunit of the NMDA ( $N$-methyl-D-aspartate) receptor (Abrahams and Geschwind 2008, Geschwind 2011, Voineagu et al. 2011). Dysregulation of excitatory and inhibitory signaling in brain has been implicated in ASD (Rubenstein 2010), suggesting that abnormal neurotransmission induced by environmental factors could exacerbate genetic predisposition for core symptoms. In line with this premise, work in rodent models has demonstrated that developmental exposure to neurotoxins can have long-term effects on glutamate, dopamine, and serotonin function, including altered sensitivity to the behavioral effects of NMDA receptor antagonists (Basta-Kaim et al. 2011, Fortier et al. 2004, Graham et al. 2012, Moy and Breese 2002, Ozawa et al. 2006, Shi et al. 2003, Vorhees et al. 2012, Zuckerman et al. 2003).

The acute administration of NMDA receptor antagonists can decrease rodent social interaction, as well as induce stereotyped, perseverative responses (Corbett et al. 1995, De Moura Linck et al. 2008, Gao et al. 2009, Nilsson et al. 2006, Nilsson et al. 2001, Steinpreis et al. 1994). Mice with reduced function of Grin 1 recapitulate many ASD features, including overt social deficits, abnormal repetitive behavior, self-injurious responses, sensory hyperreactivity, and impaired sensorimotor gating (Duncan et al. 2004, Halene et al. 2009, Mohn et al. 1999, Moy et al. 2008a, Moy et al. 2012). However, most of these changes have been reported in adult mice. We have recently found that, in contrast to a marked lack of sociability in adulthood, Grin 1 knockdown mice have significant hypersociability during adolescence (Moy et al. 2012). Further, there is preliminary evidence that memantine, an NMDA antagonist, can increase social interaction in subjects with autism (Doyle and McDougle 2012). The following studies examined whether acute disruption of NMDA receptor function in adolescent C57BL/6J mice (ages 5 to 7 weeks) leads to exaggerated social preference, similar to that observed with constitutive reduction of NMDA receptors, in a three-chamber choice task. 
Significant impairment of social interaction has also been reported following dysregulation of dopaminergic (Gendreau et al. 1998, Gendreau et al. 2000, Rodriguiz et al. 2004, Steinpreis et al. 1994) and serotonergic (Homberg et al. 2007, Zhuang et al. 1999; for reviews, see Gingrich and Hen 2001, Insel and Winslow 1998) neurotransmission in animal models. Therefore, the effects of MK-801 (Dizocilpine), an NMDA receptor antagonist, on social approach were compared to those of amphetamine, a dopamine agonist, and fluoxetine, a selective serotonin reuptake inhibitor. In addition, the role of anxiety in social deficits was investigated by testing mice following withdrawal from chronic ethanol, which has been shown to induce anxiety-like behavior and social interaction deficits in rats (File et al. 1993, Knapp et al. 2004, Moy et al. 1997, Wills et al. 2010).

The marble-burying assay has been proposed as a measure of perseverative motor responses, relevant to abnormal repetitive behavior in autism, obsessive-compulsive disorder, and other neuropsychiatric conditions (Jimenez-Gomez et al. 2011, Londei et al. 1998, Takeuchi et al. 2002, Thomas et al. 2009). Although Grin1 knockdown mice exhibit hyperactivity and increased stereotypy, including over-grooming to the point of self-injury, they have profound deficits in marble-burying (Riddick et al. 2011). Similarly, MK-801 treatment in ICR mice has been shown to attenuate marble-burying, but at a dose with significant stimulant effects on locomotor activity (Egashira et al. 2008). The present studies determined the effects of MK-801 and amphetamine on marble-burying at low doses that did not alter sociability or, in the case of MK-801, change entries in the social approach task.

\section{Material and methods}

\subsection{Animals}

Sets of male C57BL/6J mice ( $\mathrm{n}=12-24$ mice) were purchased from the Jackson Laboratory (JAX; Bar Harbor, ME), or obtained from C57BL/6J breeding pairs from JAX. Mice received from JAX were 3 to 4 weeks of age upon arrival, and were given one week to acclimate to the new housing conditions. Mice were group-housed in ventilated cages, and given free access to water and Prolab RMH 3000 chow, or water and liquid diet for the ethanol study (described below). The housing room had a 12-hr light/dark cycle (lights off at 7:00 p.m.). All procedures were conducted in strict compliance with the policies on animal welfare of the National Institutes of Health (stated in the "Guide for the Care and Use of Laboratory Animals," Institute of Laboratory Animal Resources, National Research Council, 1996 edition) and the University of North Carolina.

\subsection{Study design}

\subsubsection{Effects of altered NMDA, dopamine, or serotonin function on social} approach-4-5 separate sets of mice (JAX) were used to test each compound: MK-801 $(0.2,0.3$, or $0.5 \mathrm{mg} / \mathrm{kg})$, amphetamine $(1.0,2.0$, or $3.0 \mathrm{mg} / \mathrm{kg})$, and fluoxetine $(5.0,10.0$, and $20.0 \mathrm{mg} / \mathrm{kg}$ ), with at least half of the subjects from each separate set treated with vehicle. At 4-5 weeks in age, mice were given a one-hour open-field session, without any drug treatment. This procedure served to familiarize mice with the laboratory setting and with exploration of a novel environment. At 5-7 weeks of age, each mouse was given a single drug or vehicle treatment, and then tested in the 3-chamber choice task for social approach. A separate set of mice $(\mathrm{n}=25$; JAX) was tested with vehicle and fluoxetine $(10 \mathrm{mg} / \mathrm{kg})$, to confirm selective drug effects observed in the first group. For each test, experimenters were blinded to drug treatment condition.

2.2.2 Effects of ethanol withdrawal on social approach-At 5-6 weeks of age, mice $(\mathrm{n}=8$; JAX) were weighed, housed 2 per cage, and placed for 14 days on a modified Lieber-DeCarli liquid diet (PMI Micro-Stabilized Alcohol Rodent Liquid Diet; Test Diet, 
Richmond, IN). The diet included 5\% sucrose to increase palatability. Mice continued to have free access to water throughout the liquid diet regimen. For the first 2 days of the regimen, all mice were given regular liquid diet. The control group $(n=4)$ remained on this diet for the entire regimen. For the ethanol-withdrawal group $(n=4)$, mice were introduced to liquid diet containing $2.4 \%$ ethanol for 2 days, and then received $4.8 \%$ ethanol for the following 10-day period. The amount of diet given to the control group was matched to the mean amount of diet consumed by the ethanol-treatment group on the previous day, to insure both groups were drinking the same overall amount. On the morning of the test day, the ethanol liquid diet was replaced with regular liquid diet to induce withdrawal in the ethanol-exposed mice. 5-6 hours after replacement of the ethanol diet, mice were evaluated in the 3-chamber test for sociability, but not the test for social novelty (due to time constraints of the withdrawal period).

\subsubsection{Effects of reduced NMDA-receptor function on marble-burying-Two sets}

of mice were evaluated for MK-801 effects on marble-burying. Subjects in the first set were experimentally-naïve, male C57BL/6J mice $(\mathrm{n}=24)$, bred in the UNC animal facility. Each mouse received one test with either MK-801 $(0.2$ or $0.3 \mathrm{mg} / \mathrm{kg})$ or vehicle $(\mathrm{n}=8$ per treatment group). Subjects in the second set were 25 C57BL/6J mice (JAX) first used to confirm effects of fluoxetine $(10 \mathrm{mg} / \mathrm{kg})$ in the social approach test. One-two weeks following the social test, mice were re-assigned to 3 treatment groups $(0.05$ or $0.1 \mathrm{mg} / \mathrm{kg}$ MK-801, or vehicle, with 8-9 mice per group), balanced for initial fluoxetine or vehicle exposure, and assessed for marble-burying.

2.2.4 Effects of enhanced dopamine function on marble-burying-Subjects were experimentally-naïve, male C57BL/6J mice $(\mathrm{n}=21)$, bred in the UNC animal facility. Each mouse first received one marble-bury test with either amphetamine $(1.0$ or $2.0 \mathrm{mg} / \mathrm{kg}$ ) or vehicle ( $n=7$ per treatment group). One week later, all subjects were re-assigned to 2 new treatment groups (balanced for initial drug exposure), and re-tested in the marble-bury assay. Treatments for this second test were $1.5 \mathrm{mg} / \mathrm{kg}$ amphetamine ( $\mathrm{n}=10 \mathrm{mice}$ ), and vehicle $(\mathrm{n}=11$ mice) .

\subsection{Testing procedures}

2.3.1 Three-chamber social choice test-Mice were tested in an automated 3chamber box, using our published methods (Moy et al. 2004, Moy et al. 2007, Nadler et al. 2004). Dividing walls had retractable doorways allowing access into each chamber. The automated box had photocells embedded in each doorway to allow quantification of entries and duration in each chamber of the social test box. The chambers of the apparatus were cleaned with water and dried with paper towels between each subject. At the end of each test day, the apparatus was sprayed with $70 \%$ ethanol and wiped clean with paper towels. The choice test had 3 consecutive 10-min phases, conducted in the same test session:

1. Habituation. The test mouse was first placed in the middle chamber and allowed to explore, with the doorways into the two side chambers open.

2. Sociability. After the habituation period, the test mouse was enclosed in the center compartment of the social test box, and an unfamiliar mouse (stranger 1; a male C57BL/6J adult) was enclosed in a wire cage (Galaxy Cup, Spectrum Diversified Designs, Inc., Streetsboro, Ohio) and placed in a side chamber. All stranger mice had been previously habituated to the wire cage across at least 3 days ( 5 min per day on the first 2 days, and $10 \mathrm{~min}$ on day 3 ). The location for stranger 1 alternated between the left and right sides of the social test box. An empty wire cage was placed in the opposite side, to serve as a novel object control. Following placement of stranger 1, the doors were re-opened, and the subject was allowed to explore the 
entire social test box. Measures were taken of the amount of time spent in each chamber and the number of entries into each chamber by the automated testing system. In addition, the amount of time spent sniffing each of the wire cages was recorded by a human observer.

3. Preference for social novelty. At the end of the sociability test, each mouse was further tested for preference to spend time with a more-novel stranger. A new unfamiliar mouse (stranger 2) was placed in the wire cage that had been empty during the previous session. The test mouse then had a choice between the first, already-investigated mouse (stranger 1) and the novel unfamiliar mouse (stranger 2). The same measures were taken as with the sociability test.

2.3.2 Marble-burying assay-Mice were tested in a standard housing cage located in a sound-attenuating chamber with houselight and fan. The cage contained $5 \mathrm{~cm}$ deep corncob bedding, with 20 black glass marbles ( $14 \mathrm{~mm}$ diameter) arranged in an equidistant $5 \times 4$ grid on top of the bedding. Animals were given access to the marbles for $30 \mathrm{~min}$. Measures were taken of the number of buried marbles ( $2 / 3$ of the marble covered by the bedding) by an observer blind to drug treatment.

\subsection{Drugs}

MK-801 ((+)-MK-801 hydrogen maleate), amphetamine (D-amphetamine sulfate), and fluoxetine HCL were purchased from Sigma Chemicals (St. Louis, IL), and administered either $20 \mathrm{~min}$ (MK-801 and fluoxetine) or $10 \mathrm{~min}$ (amphetamine) before a 10-min habituation period in the social test box. Low to moderate doses of MK-801 and amphetamine were used to minimize confounding locomotor effects. Fluoxetine treatment included doses found to be anxiogenic in mice tested on the elevated plus maze $(10 \mathrm{mg} / \mathrm{kg}$; (Uz et al. 2004)) or in a novel-box environment (20 mg/kg; (Belzung et al. 2001)). Dose concentration was based on the salt weight of each compound. Ethanol was administered as described in section 2.2.2 and published reports (Parnell et al. 2007).

\subsection{Data analysis}

Statview (SAS Inc., Cary, NC) was used for data analyses. One-way or repeated measures Analysis of Variance (ANOVAs) were used to determine effects of drug dose on social behavior and marble-burying. Post-hoc comparisons to vehicle means were conducted with Fisher's Protected Least Significant Difference (PLSD) tests only when significant treatment effects were found in the overall ANOVAs. Within-dose group repeated measures ANOVAs were used to determine side preferences in the social approach assay. For all comparisons, significance was set at $p<0.05$.

\section{Results}

\subsection{Effects of MK-801 on social approach}

3.1.1 Sociability-The results showed that treatment with MK-801 could attenuate social preference at doses that had no effects on exploration during the social approach task. In the sociability test (Figure 1A,B), highly significant effects of MK-801 were observed for time spent in each side [main effect of treatment, $F(3,53)=15.35$, $p<0.0001$ ] and sniffing at each cage [main effect of treatment, $\mathrm{F}(3,53)=8.94, \mathrm{p}<0.0001$, treatment $\mathrm{x}$ side interaction, $\mathrm{F}(3,53)=6.67, \mathrm{p}=0.0007]$. At a dose of $0.3 \mathrm{mg} / \mathrm{kg}$, mice no longer demonstrated a significant preference for the stranger side, in comparison to an empty cage. However, this dose did not alter number of entries [Figure 2A; post-hoc tests following main effect of treatment, $\mathrm{F}(3,53)=4.8, \mathrm{p}=0.005]$, suggesting that the changes in social interest were not due to a lack of exploration during the test. 
3.1.2 Social novelty-The control groups given vehicle showed the predicted shift in preference to the newly-introduced stranger 2 in the social novelty test (Figure 3A,B). Treatment with MK-801, even at the low $0.2 \mathrm{mg} / \mathrm{kg}$ dose, disrupted this shift in preference, whether measured by time in each side [main effect of treatment, $F(3,53)=7.83$, $p=0.0002$ ] or sniffing at each cage [main effect of treatment, $F(3,54)=3.12, p=0.0336$, treatment $x$ side interaction, $\mathrm{F}(3,54)=3.96, \mathrm{p}=0.0127]$. At the same time, only the highest dose of MK-801 led to a change in number of entries during the social novelty test [Figure 2B; post-hoc tests following main effect of treatment, $F(3,53)=2.99$, $p=0.039$ ]

\subsection{Effects of amphetamine on social approach}

3.2.1 Sociability-Amphetamine did not disrupt sociability to the same extent as MK-801 (Figure 1C,D). A repeated measures ANOVA did not reveal any significant effects of amphetamine treatment on time spent in each side, although mice no longer demonstrated a significant preference for the side with the stranger 1 mouse at the two higher doses (2.0 and $3.0 \mathrm{mg} / \mathrm{kg}$ ). This trend towards reduced social approach following amphetamine treatment was significant when measured by time spent sniffing each wire cage [main effect of treatment, $F(3,66)=4.63, p=0.0053$; treatment $x$ side interaction, $F(3,66)=3.78, p=0.0144]$. Amphetamine had strong stimulant effects during the social approach test (Figure 2C), with higher numbers of entries observed in the test for sociability at every drug dose [main effect of treatment, $\mathrm{F}(3,66)=29.63, \mathrm{p}<0.0001]$.

3.2.2 Social novelty-In the test for social novelty preference (Figure 3C,D), there were no significant effects of amphetamine treatment on either time spent in each side, or time spent sniffing each wire cage. However, none of the groups treated with amphetamine demonstrated a preference for spending more time in the side containing the newlyintroduced stranger 2 (Figure 3C). As in the first phase of testing, amphetamine led to overt increases in entries [Figure 2D; main effect of treatment, $F(3,66)=21.52, \mathrm{p}<0.0001$ ].

\subsection{Effects of fluoxetine on social approach}

Previous studies have reported that, at a dose of $10 \mathrm{mg} / \mathrm{kg}$, fluoxetine increases low levels of sociability in BTBR $T+t f J \mathrm{~J}$ mice, a model for autism-like behavior (Chadman 2011, Gould et al. 2011), but at a higher dose $(30 \mathrm{mg} / \mathrm{kg})$, fluoxetine reduces social preference in C57BL/ $6 \mathrm{~J}$ mice (Chadman 2011). In the present study, fluoxetine led to decreased sociability in C57BL/6J mice (Figure 1E,F), but this effect was not consistent with increasing drug dose. In particular, mice treated with the low $(5 \mathrm{mg} / \mathrm{kg})$ or high $(20 \mathrm{mg} / \mathrm{kg})$ doses of fluoxetine spent significantly less time sniffing at the cage containing the stranger mouse [post-hoc tests followed repeated measures ANOVA; main effect of treatment, $F(3,53)=4.72$, $\mathrm{p}=0.0054$; trend for significant treatment $\mathrm{x}$ side interaction, $\mathrm{F}(3,53)=2.66, \mathrm{p}=0.0579]$. Further examination of the data indicated the $10 \mathrm{mg} / \mathrm{kg}$ dose of fluoxetine did not alter sociability but, in the social novelty test, attenuated preference for spending more time with the second stranger (Figure 3E). This selective sparing of sociability with concomitant disruption of social novelty preference by a moderate dose of fluoxetine was replicated in a separate set of adolescent mice (Figure 4). Fluoxetine did not change number of entries during the social approach task at any dose in the first sets of mice (Figure 2E,F), or in the separate set tested with the $10 \mathrm{mg} / \mathrm{kg}$ dose (data not shown).

\subsection{Social approach during withdrawal from chronic ethanol}

Although the subject numbers in the treatment groups were low (4 control diet and 4 ethanol diet mice), the results clearly indicated that withdrawal from chronic ethanol did not disrupt sociability, but did lead to overt reductions in exploration (Figure 5). Both the control group and the withdrawal group had strong preference for spending more time in the side 
containing the stranger mouse [within-group analyses following significant effect of side in overall ANOVA, $\mathrm{F}(1,6)=110.68, \mathrm{p}<0.0001$ ] and sniffing the stranger's cage [effect of side in overall ANOVA, $\mathrm{F}(1,6)=97.03$, $\mathrm{p}<0.0001]$. Although chronic ethanol exposure did not alter sociability, the ethanol-withdrawal group had significantly fewer entries between sides, in comparison to the control diet mice [main effect of treatment, $\mathrm{F}(1,6)=16.0$, $\mathrm{p}=0.0071$; treatment $x$ side interaction, $F(1,6)=8.33$, $\mathrm{p}=0.0278]$.

\subsection{MK-801 and amphetamine effects on marble-burying}

3.5.1 MK-801 disruption of marble-burying-The marble-burying assay has been proposed as a measure of perseverative motor responses (Jimenez-Gomez et al. 2011, Londei et al. 1998, Takeuchi et al. 2002, Thomas et al. 2009). Treatment with MK-801 led to marked decreases in marble-burying (Figure 6), even at doses that did not disrupt sociability or alter exploration during the social test. Highly significant effects of MK-801 $(0.2$ and $0.3 \mathrm{mg} / \mathrm{kg}$ ) were found for the first set of mice $[\mathrm{F}(2,21)=23.44, \mathrm{p}<0.0001]$. Because the lower dose of MK-801 $(0.2 \mathrm{mg} / \mathrm{kg})$ almost eliminated marble-burying, a separate set of mice were evaluated with even lower doses. The results showed that $0.1 \mathrm{mg} / \mathrm{kg}$, but not 0.05 $\mathrm{mg} / \mathrm{kg}$, also significantly reduced marble-burying [post-hoc tests following 1-way ANOVA, $\mathrm{F}(2,22)=7.97, \mathrm{p}=0.0025]$.

3.5.2 Amphetamine disruption of marble-burying-The initial results with amphetamine indicated a steep dose-response function, with no change at a dose of $1.0 \mathrm{mg}$ / $\mathrm{kg}$, and a virtual loss of marble-burying at $2.0 \mathrm{mg} / \mathrm{kg}$ [post-hoc tests following 1-way ANOVA, $F(2,18)=20.37, \mathrm{p}<0.0001]$. Therefore, one week following the first test, mice were re-evaluated with either vehicle or $1.5 \mathrm{mg} / \mathrm{kg}$ amphetamine. The results showed that a partial loss of marble-burying occurred at the mid-point dose, confirming an orderly relationship between dose and response $[\mathrm{F}(1,19)=19.37, \mathrm{p}=0.0003]$.

\section{Discussion}

The present studies demonstrate that modest alterations in glutamatergic, dopaminergic, or serotonergic function by treatment with neuroactive compounds can disrupt social preference in adolescent mice, dependent on dose and behavioral measure. MK-801, amphetamine, and fluoxetine all led to a loss of significant social preference, measured by time spent in each side chamber. Further, all three compounds decreased sniffing directed toward a stranger mouse during a test for sociability. However, only MK-801, at a dose of $0.3 \mathrm{mg} / \mathrm{kg}$, attenuated preference for sniffing a stranger mouse versus a non-social novel. In the test for social novelty, MK-801 (at every dose) abolished preference for the less familiar second stranger, whether measured by time in proximity or time spent sniffing. Low doses of MK-801 $(0.2 \mathrm{mg} / \mathrm{kg})$ or amphetamine $(2.0 \mathrm{mg} / \mathrm{kg})$ markedly reduced the number of marbles buried in a typically robust digging assay, used to model the restricted interests and repetitive behavior characteristic of autism. Overall, the results suggest that both social approach and exploration of novelty are particularly susceptible to disruption by aberrant glutamate function, which could be relevant to mechanisms in autism core symptoms.

\subsection{MK-801 and amphetamine effects on social approach}

Genetic reduction of NMDA receptor function can disrupt social approach. Several studies have shown that mice with reduced expression of the NR1 NMDA receptor subunit (encoded by the Grin1 gene) have marked deficiencies in social behavior, including a lack of sociability in the three-chamber choice task (Duncan et al. 2004, Halene et al. 2009, Mohn et al. 1999, Moy et al. 2012). However, we have recently found that the sociability deficits are dependent upon age: when tested in adolescence, Grin1 mutant mice demonstrate overt hypersociability, rather than a lack of social preference (Moy et al. 2012), raising the 
possibility that decreased NMDA neurotransmission could have a pro-social effect in young mice. The present findings indicate that treatment with MK-801 leads to deficits in social approach at doses that do not alter exploration and activity during the test. Acute treatment with amphetamine also attenuated social preference, but at doses that increased activity during the test. While both MK-801 and amphetamine significantly decreased sniffing directed towards the stranger mouse in the sociability test, only MK-801 significantly attenuated sniffing directed towards the empty wire cage. These results suggest that MK-801, but not amphetamine, disrupted both social motivation and a more general drive towards novel stimuli, in line with the loss of preference for the second, less-familiar stranger mouse observed at every MK-801 dose.

\subsection{Effects of fluoxetine and withdrawal from chronic ethanol on social approach}

SLC6A4, which encodes the serotonin transporter (also known as 5-HTT or SERT), has been implicated as an autism susceptibility gene in multiple studies (Coutinho et al. 2007, Devlin et al. 2005, Kistner-Griffin et al. 2010, Sutcliffe et al. 2005, Wassink et al. 2007). We have previously found that loss of Slc6a4 in mice leads to significant reductions in sociability (Moy et al. 2008b). Although chronic treatment with fluoxetine, a selective inhibitor of the serotonin transporter, has antianxiety and antidepressant effects in humans, acute fluoxetine treatment can have anxiogenic effects in humans (Gorman et al. 1987) and in mice (Belzung et al. 2001, Uz et al. 2004). The present study showed inconsistent effects of fluoxetine on social approach. In particular, mice treated with 5.0 or $20.0 \mathrm{mg} / \mathrm{kg}$ fluoxetine did not have significant preference for the side of the test box containing the stranger mouse; however, a dose of $10 \mathrm{mg} / \mathrm{kg}$ appeared to have no effect on sociability, but attenuated social novelty preference. A second group of mice confirmed the selective effects of the $10 \mathrm{mg} / \mathrm{kg}$ fluoxetine dose. Interestingly, this same dose of fluoxetine has been shown to increase sociability, but disrupt social novelty preference, in the BTBR $\mathrm{T}+\mathrm{tf} / \mathrm{J}$ (BTBR) inbred mouse strain, a model of social deficits in autism (Gould et al. 2011; see also Chadman 2011).

One question was whether acute fluoxetine treatment had anxiogenic effects in the adolescent mice. Chadman (2011) has shown that fluoxetine (10 and $30 \mathrm{mg} / \mathrm{kg}$ ) does not change percent time spent on the open arms of an elevated maze, a standard measure of anxiety-like behavior, in either BTBR or C57BL/6 adult mice. In the present study, fluoxetine did not alter exploration during the three-chamber choice test at any dose, suggesting that the changes in social approach were not explained by increased anxiety-like behavior. To further determine possible effects of enhanced anxiety on social approach, we tested mice during withdrawal from a chronic ethanol regimen. Previous work in rat models has shown that ethanol withdrawal leads to anxiety-like responses in the elevated plus maze and decreased social interaction (File et al. 1993, Knapp et al. 2004, Moy et al. 1997, Wills et al. 2010). Although only four mice were evaluated following ethanol exposure, levels of sociability were robustly significant. At the same time, the withdrawal group had overt reductions in entries during the test, indicating that the ethanol exposure had selective, detrimental effects on exploration, but not social approach. Overall, the findings do not support increased anxiety as a factor in the reduced social preference observed with MK-801, amphetamine, or fluoxetine.

\subsection{Selective disruption of social novelty preference}

The selective effects of fluoxetine $(10 \mathrm{mg} / \mathrm{kg})$ on social novelty preference, versus sociability, were also evident for MK-801 and amphetamine. At the lowest doses, MK-801 $(0.2 \mathrm{mg} / \mathrm{kg})$ and amphetamine $(1.0 \mathrm{mg} / \mathrm{kg})$ did not attenuate preference for the stranger mouse versus a novel object in the sociability test, but did prevent a preference for stranger 2 , in comparison to the more-familiar stranger 1 , in the social novelty task. A similar pattern 
of significant sociability, with a loss of social novelty preference, has been observed in mice with disruption of the glycine receptor site of the NMDA receptor complex (Labrie et al. 2008), or with partial loss of Neuregulin1, which regulates NMDA receptor function (Moy et al. 2009). Similarly, treatment with diazepam or scopolamine can selectively disrupt performance in the social novelty phase of the three-chamber procedure (Riedel et al. 2009). Motivation in the social novelty task includes a general preference for social proximity and a more specific preference for social novelty, and the ability to discriminate between a newlyintroduced stranger versus an already-investigated stranger. Thus, the more complex motivation and demands in this phase could make performance more susceptible to detrimental effects from even modest alterations in glutamate, dopamine, or serotonin function.

A drawback to the social novelty task is that the magnitude of preference between two stranger mice is typically less than the magnitude of preference between social and nonsocial stimuli in the sociability phase (present study; Moy et al. 2007). The weaker preference for stranger 2 in control mice can make the detection of alterations from genetic or environmental factors more difficult. Our research group has shown that extending the sociability phase of the three-chamber test to 20 minutes allows greater habituation to the first stranger, leading to more robust preference for stranger 2 in the first 5 minutes of the subsequent social novelty task (Nadler et al. 2004). It is notable that Riedel and colleagues (2009) found significant preference for stranger 2 versus stranger 1 following a 10-minute delay between the sociability and social novelty phases, demonstrating the utility of the task as a measure of social memory.

\subsection{Effects of MK-801 and amphetamine in the marble-burying assay}

Repetitive behavior, including narrow restricted interests, stereotypy, a lack of curiosity about the environment, and cognitive rigidity, is a core symptom of ASD. The marbleburying assay has been proposed as a measure for abnormal, perseverative responses in rodent models (Jimenez-Gomez et al. 2011, Londei et al. 1998, Takeuchi et al. 2002, Thomas et al. 2009). Increased marble-burying has been reported in BTBR mice (Amodeo et al. 2012) and in Slitrk5-null mice, which also exhibit stereotyped over-grooming (Shmelkov et al. 2010). Further, prenatal exposure to valproic acid or maternal immune activation can also increase marble-burying in mice (Malkova et al. 2012, Mehta et al. 2011). In contrast, we have found that Grin 1 mutant mice have overt reductions in numbers of marbles buried (Riddick et al. 2011). Similar decreases in marble-burying have been reported in other mutant lines with autism-like phenotypes (Balemans et al. 2010, Feyder et al. 2010), suggesting that the assay could be used to model narrow, restricted interests and reduced exploration, relevant to abnormalities in autism (e.g. Pierce and Courchesne 2001, Sasson et al. 2008). In the present study, we found that MK-801 and amphetamine, at doses that did not block significant sociability, led to marked deficiencies in the marble-burying assay.

\subsection{Conclusion}

These studies demonstrate that acute reductions in NMDA receptor function, or enhancements in dopaminergic or serotonergic neurotransmission, lead to a dose-dependent loss of social preference in the three-chamber choice task. None of the compounds resulted in the hypersociability observed in adolescent mice with constitutive knockdown of NMDA receptors (Moy et al. 2012). In comparison to amphetamine and fluoxetine, MK-801 induced greater changes in social approach, including significant treatment effects on the measure of time spent in each side chamber, a loss of social novelty preference, and decreased investigation of a non-social novel object. Further, the results from the marble-burying assay indicate that novelty-induced digging could be a particularly sensitive marker for disruption of NMDA receptor function. Overall, these findings support the critical role for NMDA 
receptors in the regulation of social approach and response to novelty in mice, which could be relevant to the mechanistic basis of ASD symptoms.

\section{Acknowledgments}

Support for these studies was contributed by NIMH grant MH080069 (SSM), NICHD grant P30 HD03110 (Joe

Piven), and the UNC Bowles Center for Alcohol Studies.

\section{References}

Abrahams BS, Geschwind DH. Advances in autism genetics: on the threshold of a new neurobiology. Nature Reviews, Genetics. 2008; 9:341-355.

Amodeo DA, Jones JH, Sweeney JA, Ragozzino ME. Differences in BTBR T+ tf/J and C57BL/6J mice on probabilistic reversal learning and stereotyped behaviors. Behav Brain Res. 2012; 227:6472. [PubMed: 22056750]

Bailey A, Le Couteur A, Gottesman I, Bolton P, Simonoff E, Yuzda E, Rutter M. Autism as a strongly genetic disorder: evidence from a British twin study. Psychol Med. 1995; 25:63-77. [PubMed: 7792363]

Balemans MC, Huibers MM, Eikelenboom NW, Kuipers AJ, van Summeren RC, Pijpers MM, Tachibana M, Shinkai Y, van Bokhoven H, Van der Zee CE. Reduced exploration, increased anxiety, and altered social behavior: Autistic-like features of euchromatin histone methyltransferase 1 heterozygous knockout mice. Behav Brain Res. 2010; 208:47-55. [PubMed: 19896504]

Basta-Kaim A, Fijal K, Budziszewska B, Regulska M, Leskiewicz M, Kubera M, Golembiowska K, Lason W, Wedzony K. Prenatal lipopolysaccharide treatment enhances MK-801-induced psychotomimetic effects in rats. Pharmacol Biochem Behav. 2011; 98:241-249. [PubMed: 21236292]

Belzung C, Le Guisquet AM, Barreau S, Calatayud F. An investigation of the mechanisms responsible for acute fluoxetine-induced anxiogenic-like effects in mice. Behav Pharmacol. 2001; 12:151-162. [PubMed: 11485052]

Chadman KK. Fluoxetine, but not risperidone, increases sociability in the BTBR mouse model of autism. Pharmacol Biochem Behav. 2011; 97:586-594. [PubMed: 20863848]

Corbett R, Camacho F, Woods AT, Kerman LL, Fishkin RJ, Brooks K, Dunn RW. Antipsychotic agents antagonize non-competitive N-methyl-D-aspartate antagonist-induced behaviors. Psychopharmacology (Berl). 1995; 120:67-74. [PubMed: 7480537]

Coutinho AM, Sousa I, Martins M, Correia C, Morgadinho T, Bento C, Marques C, Ataide A, Miguel TS, Moore JH, Oliveira G, Vicente AM. Evidence for epistasis between SLC6A4 and ITGB3 in autism etiology and in the determination of platelet serotonin levels. Hum Genet. 2007; 121:243256. [PubMed: 17203304]

de Moura Linck V, Herrmann AP, Goerck GC, Iwu MM, Okunji CO, Leal MB, Elisabetsky E. The putative antipsychotic alstonine reverses social interaction withdrawal in mice. Prog Neuropsychopharmacol Biol Psychiatry. 2008; 32:1449-1452. [PubMed: 18539376]

Devlin B, Cook EH Jr, Coon H, Dawson G, Grigorenko EL, McMahon W, Minshew N, Pauls D, Smith M, Spence MA, Rodier PM, Stodgell C, Schellenberg GD. Autism and the serotonin transporter: the long and short of it. Mol Psychiatry. 2005; 10:1110-1116. [PubMed: 16103890]

Doyle CA, McDougle CJ. Pharmacotherapy to control behavioral symptoms in children with autism. Expert Opin Pharmacother. 2012; 13:1615-1629. [PubMed: 22550944]

Duncan GE, Moy SS, Perez A, Eddy DM, Zinzow WM, Lieberman JA, Snouwaert JN, Koller BH. Deficits in sensorimotor gating and tests of social behavior in a genetic model of reduced NMDA receptor function. Behav Brain Res. 2004; 153:507-519. [PubMed: 15265649]

Egashira N, Okuno R, Harada S, Matsushita M, Mishima K, Iwasaki K, Nishimura R, Oishi R, Fujiwara M. Effects of glutamate-related drugs on marble-burying behavior in mice: implications for obsessive-compulsive disorder. Eur J Pharmacol. 2008; 586:164-170. [PubMed: 18423440]

Feyder M, Karlsson RM, Mathur P, Lyman M, Bock R, Momenan R, Munasinghe J, Scattoni ML, Ihne J, Camp M, Graybeal C, Strathdee D, Begg A, Alvarez VA, Kirsch P, Rietschel M, Cichon S, Walter H, Meyer-Lindenberg A, Grant SG, Holmes A. Association of mouse Dlg4 (PSD-95) gene 
deletion and human DLG4 gene variation with phenotypes relevant to autism spectrum disorders and Williams' syndrome. Am J Psychiatry. 2010; 167:1508-1517. [PubMed: 20952458]

File SE, Andrews N, al-Farhan M. Anxiogenic responses of rats on withdrawal from chronic ethanol treatment: effects of tianeptine. Alcohol Alcohol. 1993; 28:281-286. [PubMed: 8352839]

Folstein SE, Rosen-Sheidley B. Genetics of autism: complex aetiology for a heterogeneous disorder. Nat Rev Genet. 2001; 2:943-955. [PubMed: 11733747]

Fortier ME, Joober R, Luheshi GN, Boksa P. Maternal exposure to bacterial endotoxin during pregnancy enhances amphetamine-induced locomotion and startle responses in adult rat offspring. J Psychiatr Res. 2004; 38:335-345. [PubMed: 15003440]

Gao XM, Elmer GI, Adams-Huet B, Tamminga CA. Social memory in mice: disruption with an NMDA antagonist and attenuation with antipsychotic drugs. Pharmacol Biochem Behav. 2009; 92:236-242. [PubMed: 19103218]

Gendreau PL, Petitto JM, Gariepy JL, Lewis MH. D2-like dopamine receptor mediation of socialemotional reactivity in a mouse model of anxiety: strain and experience effects. Neuropsychopharmacology. 1998; 18:210-221. [PubMed: 9471118]

Gendreau PL, Petitto JM, Petrova A, Gariepy J, Lewis MH. D(3) and D(2) dopamine receptor agonists differentially modulate isolation-induced social-emotional reactivity in mice. Behav Brain Res. 2000; 114:107-117. [PubMed: 10996052]

Geschwind DH. Genetics of autism spectrum disorders. Trends Cogn Sci. 2011; 15:409-416. [PubMed: 21855394]

Gingrich JA, Hen R. Dissecting the role of the serotonin system in neuropsychiatric disorders using knockout mice. Psychopharmacology (Berl). 2001; 155:1-10. [PubMed: 11374326]

Gorman JM, Liebowitz MR, Fyer AJ, Goetz D, Campeas RB, Fyer MR, Davies SO, Klein DF. An open trial of fluoxetine in the treatment of panic attacks. J Clin Psychopharmacol. 1987; 7:329332. [PubMed: 3500189]

Gould GG, Hensler JG, Burke TF, Benno RH, Onaivi ES, Daws LC. Density and function of central serotonin (5-HT) transporters, 5-HT1A and 5-HT2A receptors, and effects of their targeting on BTBR T+tf/J mouse social behavior. J Neurochem. 2011; 116:291-303. [PubMed: 21070242]

Graham DL, Amos-Kroohs RM, Braun AA, Grace CE, Schaefer TL, Skelton MR, Williams MT, Vorhees CV. Neonatal (+)-methamphetamine exposure in rats alters adult locomotor responses to dopamine D1 and D2 agonists and to a glutamate NMDA receptor antagonist, but not to serotonin agonists. Int J Neuropsychopharmacol. 2012:1-15. [PubMed: 22391043]

Halene TB, Ehrlichman RS, Liang Y, Christian EP, Jonak GJ, Gur TL, Blendy JA, Dow HC, Brodkin ES, Schneider F, Gur RC, Siegel SJ. Assessment of NMDA receptor NR1 subunit hypofunction in mice as a model for schizophrenia. Genes Brain Behav. 2009; 8:661-675. [PubMed: 19563516]

Hallmayer J, Cleveland S, Torres A, Phillips J, Cohen B, Torigoe T, Miller J, Fedele A, Collins J, Smith K, Lotspeich L, Croen LA, Ozonoff S, Lajonchere C, Grether JK, Risch N. Genetic heritability and shared environmental factors among twin pairs with autism. Arch Gen Psychiatry. 2011; 68:1095-1102. [PubMed: 21727249]

Herbert MR, Russo JP, Yang S, Roohi J, Blaxill M, Kahler SG, Cremer L, Hatchwell E. Autism and environmental genomics. Neurotoxicology. 2006; 27:671-684. [PubMed: 16644012]

Homberg JR, Schiepers OJ, Schoffelmeer AN, Cuppen E, Vanderschuren LJ. Acute and constitutive increases in central serotonin levels reduce social play behaviour in peri-adolescent rats. Psychopharmacology (Berl). 2007; 195:175-182. [PubMed: 17661017]

Insel TR, Winslow JT. Serotonin and neuropeptides in affiliative behaviors. Biol Psychiatry. 1998; 44:207-219. [PubMed: 9693392]

Jimenez-Gomez C, Osentoski A, Woods JH. Pharmacological evaluation of the adequacy of marble burying as an animal model of compulsion and/or anxiety. Behav Pharmacol. 2011; 22:711-713. [PubMed: 21921841]

Kistner-Griffin E, Brune CW, Davis LK, Sutcliffe JS, Cox NJ, Cook EH Jr. Parent-of-origin effects of the serotonin transporter gene associated with autism. Am J Med Genet B Neuropsychiatr Genet. 2010; 156:139-144. [PubMed: 21302342]

Knapp DJ, Overstreet DH, Moy SS, Breese GR. SB242084, flumazenil, and CRA1000 block ethanol withdrawal-induced anxiety in rats. Alcohol. 2004; 32:101-111. [PubMed: 15163561] 
Labrie V, Lipina T, Roder JC. Mice with reduced NMDA receptor glycine affinity model some of the negative and cognitive symptoms of schizophrenia. Psychopharmacology (Berl). 2008; 200:217230. [PubMed: 18597079]

Libbey JE, Sweeten TL, McMahon WM, Fujinami RS. Autistic disorder and viral infections. J Neurovirol. 2005; 11:1-10. [PubMed: 15804954]

Londei T, Valentini AM, Leone VG. Investigative burying by laboratory mice may involve nonfunctional, compulsive, behaviour. Behav Brain Res. 1998; 94:249-254. [PubMed: 9722276]

Malkova NV, Yu CZ, Hsiao EY, Moore MJ, Patterson PH. Maternal immune activation yields offspring displaying mouse versions of the three core symptoms of autism. Brain Behav Immun. 2012; 26:607-616. [PubMed: 22310922]

Mehta MV, Gandal MJ, Siegel SJ. mGluR5-antagonist mediated reversal of elevated stereotyped, repetitive behaviors in the VPA model of autism. PLoS One. 2011; 6:e26077. [PubMed: 22016815]

Mohn AR, Gainetdinov RR, Caron MG, Koller BH. Mice with reduced NMDA receptor expression display behaviors related to schizophrenia. Cell. 1999; 98:427-436. [PubMed: 10481908]

Moy SS, Breese GR. Phencyclidine supersensitivity in rats with neonatal dopamine loss. Psychopharmacology (Berl). 2002; 161:255-262. [PubMed: 12021828]

Moy SS, Ghashghaei HT, Nonneman RJ, Weimer JM, Yokota Y, Lee D, Lai C, Threadgill DW, Anton ES. Deficient NRG1-ERBB signaling alters social approach: relevance to genetic mouse models of schizophrenia. J Neurodevelop Disord. 2009; 1:302-312.

Moy SS, Knapp DJ, Criswell HE, Breese GR. Flumazenil blockade of anxiety following ethanol withdrawal in rats. Psychopharmacology (Berl). 1997; 131:354-360. [PubMed: 9226737]

Moy SS, Nadler JJ, Perez A, Barbaro RP, Johns JM, Magnuson TR, Piven J, Crawley JN. Sociability and preference for social novelty in five inbred strains: an approach to assess autistic-like behavior in mice. Genes Brain Behav. 2004; 3:287-302. [PubMed: 15344922]

Moy SS, Nadler JJ, Poe MD, Nonneman RJ, Young NB, Koller BH, Crawley JN, Duncan GE, Bodfish JW. Development of a mouse test for repetitive, restricted behaviors: relevance to autism. Behav Brain Res. 2008a; 188:178-194. [PubMed: 18068825]

Moy SS, Nadler JJ, Young NB, Nonneman RJ, Grossman AW, Murphy DL, D’Ercole AJ, Crawley JN, Magnuson TR, Lauder JM. Social Approach in Genetically-Engineered Mouse Lines Relevant to Autism. Genes Brain Behav. 2008b; 8:129-142. [PubMed: 19016890]

Moy SS, Nadler JJ, Young NB, Perez A, Holloway LP, Barbaro RP, Barbaro JR, Wilson LM, Threadgill DW, Lauder JM, Magnuson TR, Crawley JN. Mouse behavioral tasks relevant to autism: Phenotypes of 10 inbred strains. Behav Brain Res. 2007; 176:4-20. [PubMed: 16971002]

Moy SS, Nikolova VD, Riddick NV, Baker LK, Koller BH. Preweaning Sensorimotor Deficits and Adolescent Hypersociability in Grin1 Knockdown Mice. Dev Neurosci. 2012 in press.

Nadler JJ, Moy SS, Dold G, Trang D, Simmons N, Perez A, Young NB, Barbaro RP, Piven J, Magnuson TR, Crawley JN. Automated apparatus for rapid quantitation of autism-like social deficits in mice. Genes Brain Behav. 2004; 3:303-314. [PubMed: 15344923]

Nilsson M, Markinhuhta KR, Carlsson ML. Differential effects of classical neuroleptics and a newer generation antipsychotics on the MK-801 induced behavioural primitivization in mouse. Prog Neuropsychopharmacol Biol Psychiatry. 2006; 30:521-530. [PubMed: 16414166]

Nilsson M, Waters S, Waters N, Carlsson A, Carlsson ML. A behavioural pattern analysis of hypoglutamatergic mice--effects of four different antipsychotic agents. J Neural Transm. 2001; 108:1181-1196. [PubMed: 11725821]

Ozawa K, Hashimoto K, Kishimoto T, Shimizu E, Ishikura H, Iyo M. Immune activation during pregnancy in mice leads to dopaminergic hyperfunction and cognitive impairment in the offspring: a neurodevelopmental animal model of schizophrenia. Biol Psychiatry. 2006; 59:546-554. [PubMed: 16256957]

Palmer RF, Blanchard S, Stein Z, Mandell D, Miller C. Environmental mercury release, special education rates, and autism disorder: an ecological study of Texas. Health Place. 2006; 12:203209. [PubMed: 16338635] 
Parnell SE, Chen SY, Charness ME, Hodge CW, Dehart DB, Sulik KK. Concurrent dietary administration of D-SAL and ethanol diminishes ethanol's teratogenesis. Alcohol Clin Exp Res. 2007; 31:2059-2064. [PubMed: 17949468]

Pierce K, Courchesne E. Evidence for a cerebellar role in reduced exploration and stereotyped behavior in autism. Biol Psychiatry. 2001; 49:655-664. [PubMed: 11313033]

Rasalam AD, Hailey H, Williams JH, Moore SJ, Turnpenny PD, Lloyd DJ, Dean JC. Characteristics of fetal anticonvulsant syndrome associated autistic disorder. Dev Med Child Neurol. 2005; 47:551555. [PubMed: 16108456]

Riddick NV, Agster LK, Baker LK, Koller BH, Moy SS. Marble-burying as an index of restricted interests in mouse models of repetitive behavior. Soc Neurosci Abstracts. 2011; 41:56.10.

Riedel G, Kang SH, Choi DY, Platt B. Scopolamine-induced deficits in social memory in mice: reversal by donepezil. Behav Brain Res. 2009; 204:217-225. [PubMed: 19527754]

Rodriguiz RM, Chu R, Caron MG, Wetsel WC. Aberrant responses in social interaction of dopamine transporter knockout mice. Behav Brain Res. 2004; 148:185-198. [PubMed: 14684259]

Rosenberg RE, Law JK, Yenokyan G, McGready J, Kaufmann WE, Law PA. Characteristics and concordance of autism spectrum disorders among 277 twin pairs. Arch Pediatr Adolesc Med. 2009; 163:907-914. [PubMed: 19805709]

Rubenstein JL. Three hypotheses for developmental defects that may underlie some forms of autism spectrum disorder. Curr Opin Neurol. 2010; 23:118-123. [PubMed: 20087182]

Sasson NJ, Turner-Brown LM, Holtzclaw TN, Lam KS, Bodfish JW. Children with autism demonstrate circumscribed attention during passive viewing of complex social and nonsocial picture arrays. Autism Res. 2008; 1:31-42. [PubMed: 19360648]

Shelton JF, Hertz-Picciotto I, Pessah IN. Tipping the Balance of Autism Risk: Potential Mechanisms Linking Pesticides and Autism. Environ Health Perspect. 2012

Shi L, Fatemi SH, Sidwell RW, Patterson PH. Maternal influenza infection causes marked behavioral and pharmacological changes in the offspring. J Neurosci. 2003; 23:297-302. [PubMed: 12514227]

Shmelkov SV, Hormigo A, Jing D, Proenca CC, Bath KG, Milde T, Shmelkov E, Kushner JS, Baljevic M, Dincheva I, Murphy AJ, Valenzuela DM, Gale NW, Yancopoulos GD, Ninan I, Lee FS, Rafii S. Slitrk5 deficiency impairs corticostriatal circuitry and leads to obsessive-compulsive-like behaviors in mice. Nat Med. 2010; 16:598-602. [PubMed: 20418887]

Steinpreis RE, Sokolowski JD, Papanikolaou A, Salamone JD. The effects of haloperidol and clozapine on PCP- and amphetamine-induced suppression of social behavior in the rat. Pharmacol Biochem Behav. 1994; 47:579-585. [PubMed: 8208777]

Sutcliffe JS, Delahanty RJ, Prasad HC, McCauley JL, Han Q, Jiang L, Li C, Folstein SE, Blakely RD. Allelic heterogeneity at the serotonin transporter locus (SLC6A4) confers susceptibility to autism and rigid-compulsive behaviors. Am J Hum Genet. 2005; 77:265-279. [PubMed: 15995945]

Takeuchi H, Yatsugi S, Yamaguchi T. Effect of YM992, a novel antidepressant with selective serotonin re-uptake inhibitory and 5-HT 2A receptor antagonistic activity, on a marble-burying behavior test as an obsessive-compulsive disorder model. Jpn J Pharmacol. 2002; 90:197-200. [PubMed: 12419892]

Thomas A, Burant A, Bui N, Graham D, Yuva-Paylor LA, Paylor R. Marble burying reflects a repetitive and perseverative behavior more than novelty-induced anxiety. Psychopharmacology (Berl). 2009; 204:361-373. [PubMed: 19189082]

Tian Y, Green PG, Stamova B, Hertz-Picciotto I, Pessah IN, Hansen R, Yang X, Gregg JP, Ashwood P, Jickling G, Van de Water J, Sharp FR. Correlations of gene expression with blood lead levels in children with autism compared to typically developing controls. Neurotox Res. 2011; 19:1-13. [PubMed: 19921347]

Uz T, Dimitrijevic N, Akhisaroglu M, Imbesi M, Kurtuncu M, Manev H. The pineal gland and anxiogenic-like action of fluoxetine in mice. Neuroreport. 2004; 15:691-694. [PubMed: 15094477]

Voineagu I, Wang X, Johnston P, Lowe JK, Tian Y, Horvath S, Mill J, Cantor RM, Blencowe BJ, Geschwind DH. Transcriptomic analysis of autistic brain reveals convergent molecular pathology. Nature. 2011; 474:380-384. [PubMed: 21614001] 
Volk HE, Hertz-Picciotto I, Delwiche L, Lurmann F, McConnell R. Residential proximity to freeways and autism in the CHARGE study. Environ Health Perspect. 2011; 119:873-877. [PubMed: 21156395]

Vorhees CV, Graham DL, Braun AA, Schaefer TL, Skelton MR, Richtand NM, Williams MT. Prenatal immune challenge in rats: Altered responses to dopaminergic and glutamatergic agents, prepulse inhibition of acoustic startle, and reduced route-based learning as a function of maternal body weight gain after prenatal exposure to Poly IC. Synapse. 2012 in press.

Wassink TH, Hazlett HC, Epping EA, Arndt S, Dager SR, Schellenberg GD, Dawson G, Piven J. Cerebral cortical gray matter overgrowth and functional variation of the serotonin transporter gene in autism. Arch Gen Psychiatry. 2007; 64:709-717. [PubMed: 17548752]

Williams G, King J, Cunningham M, Stephan M, Kerr B, Hersh JH. Fetal valproate syndrome and autism: additional evidence of an association. Dev Med Child Neurol. 2001; 43:202-206. [PubMed: 11263692]

Wills TA, Knapp DJ, Overstreet DH, Breese GR. Interactions of stress and CRF in ethanol-withdrawal induced anxiety in adolescent and adult rats. Alcohol Clin Exp Res. 2010; 34:1603-1612. [PubMed: 20586753]

Zhuang X, Gross C, Santarelli L, Compan V, Trillat AC, Hen R. Altered emotional states in knockout mice lacking 5-HT1A or 5-HT1B receptors. Neuropsychopharmacology. 1999; 21:52S-60S. [PubMed: 10432489]

Zuckerman L, Rehavi M, Nachman R, Weiner I. Immune activation during pregnancy in rats leads to a postpubertal emergence of disrupted latent inhibition, dopaminergic hyperfunction, and altered limbic morphology in the offspring: a novel neurodevelopmental model of schizophrenia. Neuropsychopharmacology. 2003; 28:1778-1789. [PubMed: 12865897] 


\section{Highlights}

1. Moderate alterations of NMDA, dopamine, or serotonin function attenuated social preference in adolescent mice.

2. In a three-chamber choice task, preference for social novelty was more susceptible to disruption than sociability.

3. Withdrawal from chronic ethanol consumption decreased exploration, but had no effect on sociability, during the choice task.

4. Marble-burying behavior was almost completely attenuated by an MK-801 dose $(0.2 \mathrm{mg} / \mathrm{kg})$ that did not disrupt sociability in adolescent mice. 

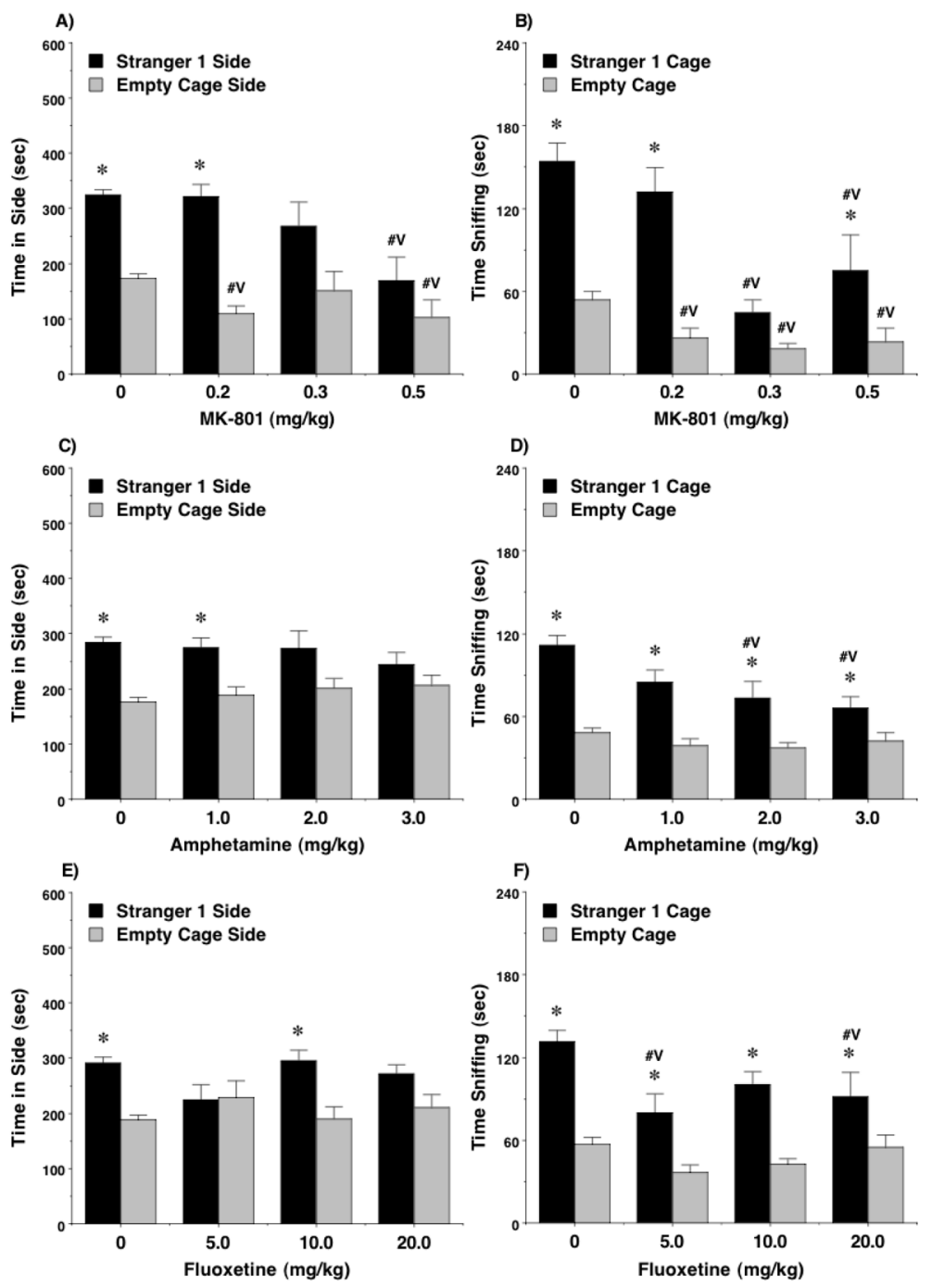

Figure 1. Effects of MK-801, amphetamine, and fluoxetine on sociability in adolescent mice Data shown are means (+ SEM) for 9-10 mice per drug treatment group, and 29-40 mice per vehicle treatment group. Data for time spent in each side were lost for one mouse from the MK-801 group, and data for sniffing were lost from three mice (one in the MK-801 group and two in the fluoxetine group), due to equipment failure or experimenter error. ${ }^{\#} \mathbf{v}_{\mathrm{p}}<0.05$, comparison with vehicle. ${ }^{*} \mathrm{p}<0.05$, within-treatment comparison to opposite side. 

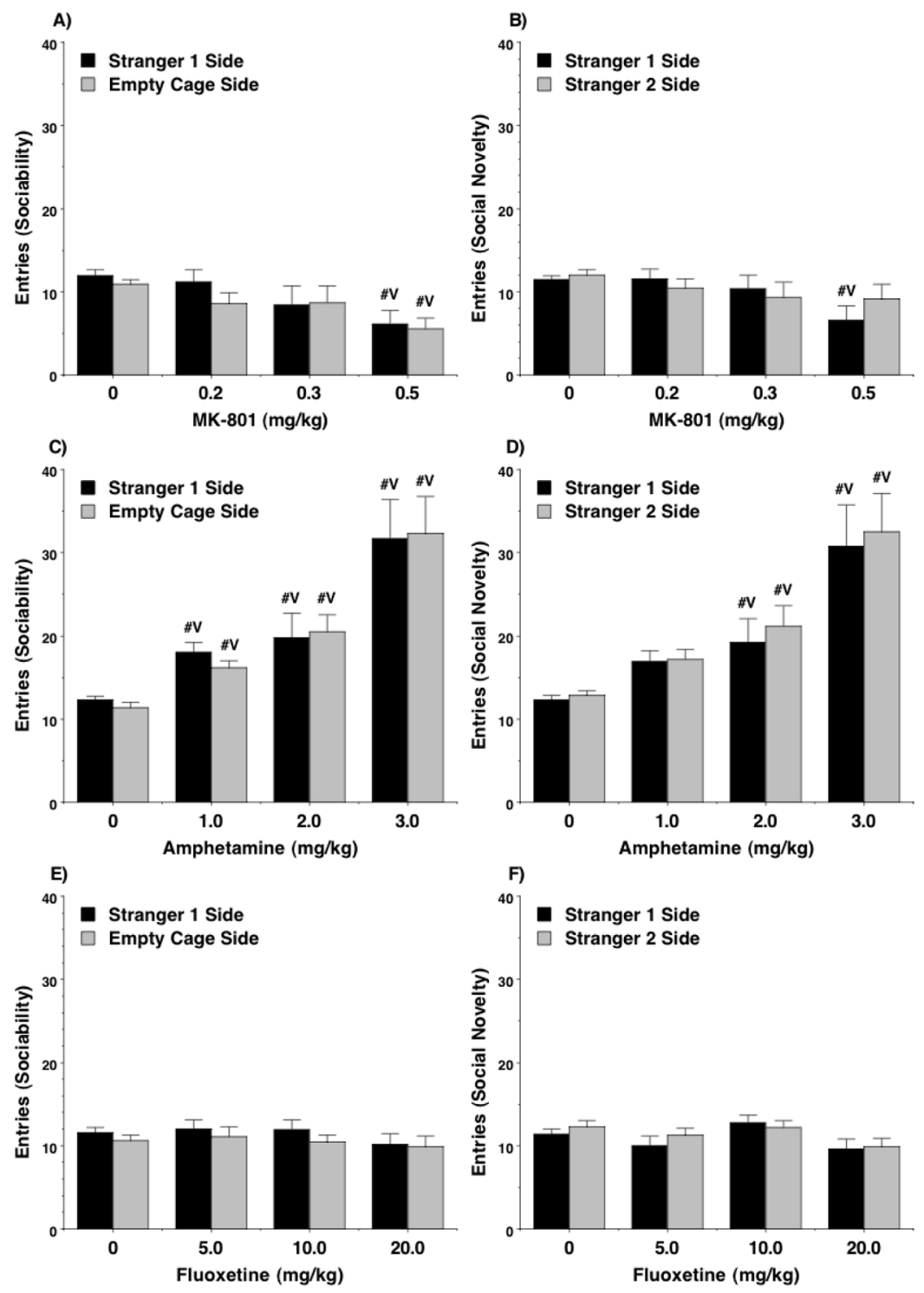

Figure 2. Effects of MK-801, amphetamine, and fluoxetine on entries during the sociability (A, $\mathrm{C}$, and $\mathrm{E})$ and social novelty $(\mathrm{B}, \mathrm{D}$, and $\mathrm{F})$ tests

The measure for entries served as an index for exploration and activity during the 3-chamber choice task. ${ }^{\# \mathrm{~V}}<0.05$, comparison with vehicle. 

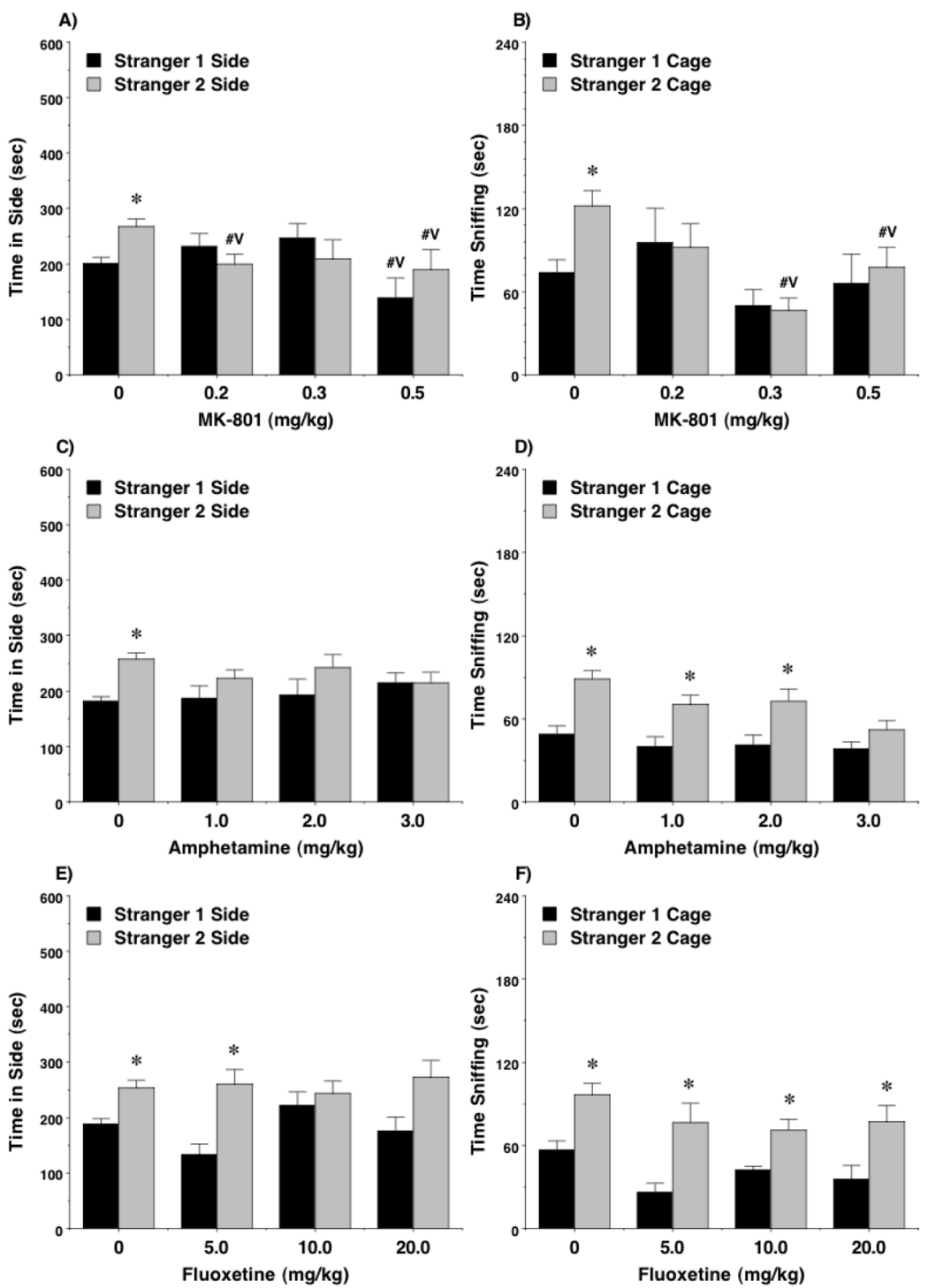

Figure 3. Effects of MK-801, amphetamine, and fluoxetine on social novelty preference MK-801 attenuated preference for the newly-introduced stranger 2 mouse, in comparison to

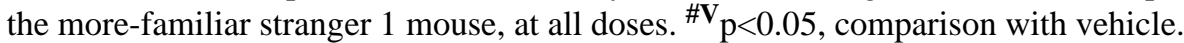
$* \mathrm{p}<0.05$, within-treatment comparison to opposite side. 

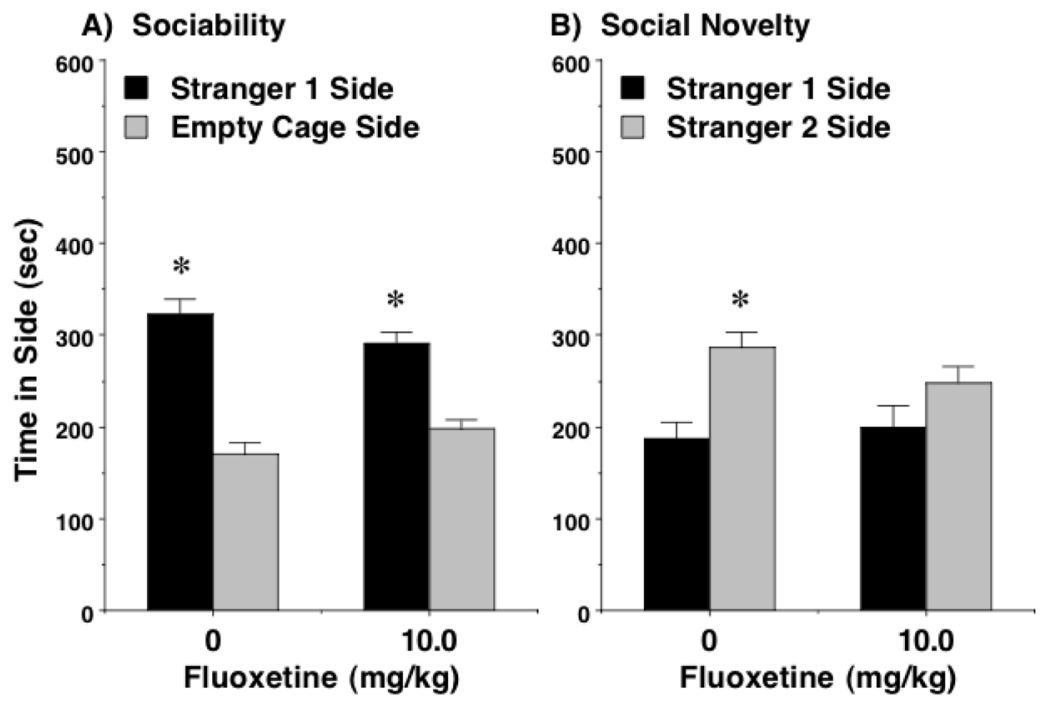

Figure 4. Selective disruption of social novelty preference, but not sociability, by fluoxetine (10.0 $\mathbf{m g} / \mathbf{k g}$ )

Results are from a separate set of C57BL/6J male mice (age 5-6 weeks), tested to confirm initial findings on fluoxetine effects, shown in Figures $1 \mathrm{E}$ and $3 \mathrm{E} . \mathrm{N}=12$ mice treated with vehicle, and 13 mice treated with fluoxetine. ${ }^{*} \mathrm{p}<0.05$, within-treatment comparison to opposite side. 

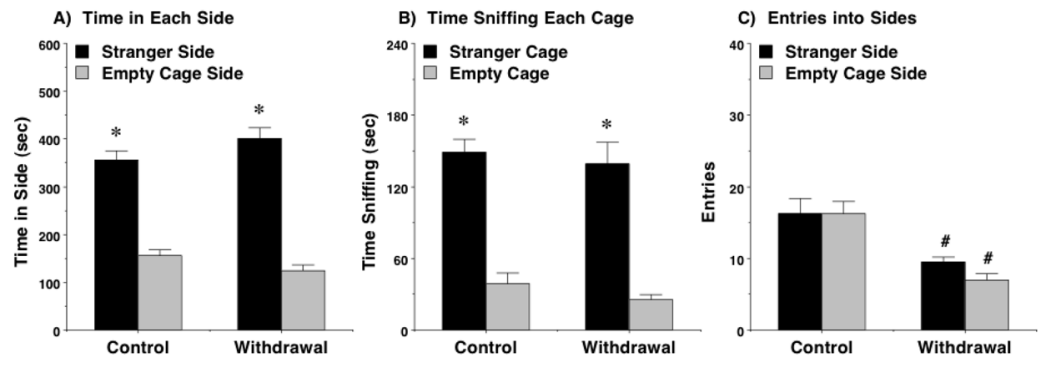

Figure 5. No disruption of sociability during withdrawal from chronic ethanol Mice were tested 5-6 hours following withdrawal from a 12-day regimen of ethanol liquid diet, or after exposure to control liquid diet. $\mathrm{N}=4$ mice per treatment group. ${ }^{\#} \mathrm{p}<0.05$, comparison with group given control liquid diet. $* \mathrm{p}<0.05$, within-group comparison to opposite side. 

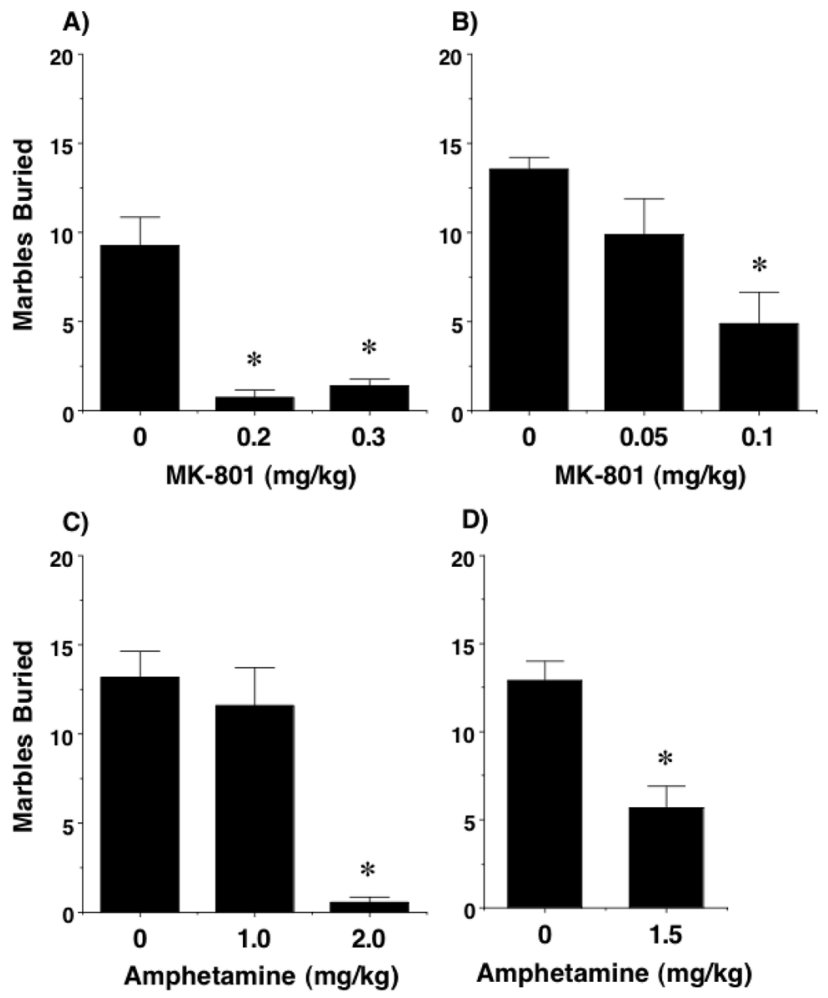

Figure 6. Dose-dependent attenuation of marble-burying by MK-801 and amphetamine Data shown are means (+ SEM) from 7-11 mice per vehicle and drug dose, with two separate sets of mice tested for MK-801 (A and B). Mice given amphetamine received two tests: a first test (C) with two low drug doses (1.0 and $2.0 \mathrm{mg} / \mathrm{kg})$, and a second test (D), one week later, with a mid-range dose $(1.5 \mathrm{mg} / \mathrm{kg})$. Groups in (D) were balanced across drug treatment in the first test. $* \mathrm{p}<0.05$, comparison to vehicle group. Disruption of social approach by MK-801, amphetamine, and fluoxetine in adolescent C57BL/6J mice 